Seyahat ve Otel İşletmeciliği Dergisi/

Journal of Travel and Hospitality Management

16 (3), 2019, 456-469.

Gönderim Tarihi:03.08.2019

Kabul Tarihi:16.09.2019

\title{
Lisans Turist Rehberliği Öğrencilerinde Öğrenme Stillerinin Genel Akademik Başarı Puanına Etkisi*
}

\section{The Effect of Learning Style of the Undergraduate Students of Tourism Guidance on Their Cumulative Grade Point Average}

\author{
Dr. Öğr. Üyesi Seçkin ESER \\ Kırklareli Üniversitesi \\ Turizm Fakültesi \\ E-posta: seckineser@outlook.com
}

\author{
Prof.Dr. A.Celil ÇAKICI \\ Mersin Üniversitesi \\ Turizm Fakültesi \\ E-posta: celilcakici@gmail.com
}

\section{Öz}

Bireylerin öğrenme stil tercihleri farkılık gösterir. Bazı bireyler birden fazla öğrenme stilini kullanmayı da tercih edebilirler. Öğrenme sürecinde en etkin öğrenme stilinin/ stillerinin tercihi sürecin kısalmasını ve etkin bir öğrenme yolunun oluşmasına yardımcı olabilmektedir. Çalışmanın amacı lisans düzeyinde turizm rehberliği eğitimi alan öğrencilerin öğrenme stillerinin genel akademik başarı puanlarına etkisinin belirlenmesidir. Veriler, literatüre dayalı geliştirilen bir anketin Türkiye'de lisans düzeyinde turizm rehberliği eğitimi alan 1105 öğrenciye uygulanmasıyla derlenmiştir. Anketler, öğrencilere 2016-2017 eğitim-öğretim yılı bahar yarıyılında, turizm rehberliği bölümlerinde görevli öğretim elemanlarının yardımıyla, sınıf bazında kota örneklemesine göre, 10.02-20.03.2017 tarihleri arasında yüz yüze uygulanmıştır. Verilerin analizinde, tanımlayıcı istatistiklerin yanı sıra t-testi, ANOVA ve çoklu regresyon analizinden yararlanılmıştır. Lisans düzeyinde turizm rehberliği öğrencilerin genel başarı puanlarında öğrenme stillerinin etkili olduğu belirlenmiştir. Öğrencilerin görsel öğrenme stillerini tercih ettiği belirlenmiştir. Çalışma, lisans düzeyinde rehberlik eğitimi alan öğrencilerin, genel başarı puanlarının arttırılmasına yönelik çeşitli öneriler ile son bulmaktadır.

Anahtar Kelimeler: Turizm rehberliği, öğrenme stilleri, lisans öğrencileri, genel akademik başarı puanı

\begin{abstract}
This study aims to determine the effect of learning styles of the undergraduate students of tourism guidance on their cumulative grade point average. The data were collected via a questionnaire developed based on the literature to 1105 students who received tourism guidance education at undergraduate level in Turkey. The questionnaires were implemented to the students face to face with the help of the lecturers in the tourism guidance departments in the spring semester of 2016-2017 academic year, according to quota sampling based on the class. The data were subjected to t-test, ANOVA, and multiple regression analysis besides descriptive statistics. It was determined that learning styles were effective on the cumulative grade point average of tourism guidance students at undergraduate level. It is determined that students prefer visual learning styles. The study concludes with various suggestions for increasing the cumulative grade point averages of the students who receive guidance education at undergraduate level.
\end{abstract}

Key Words: Tourism guidance, learning style, undergraduate students, cumulative grade point average

*Bu çalışma, S. Eser'in (2017) "Kişilik Özelliklerinin Mesleğe Yönelik Tutuma Etkisinde Öğrenme Stilleri ve Akademik Motivasyonun Aracılık Rolü: Lisans Turizm Rehberliği Öğrencileri Üzerine Bir Araştırma” başlıkı tezinden üretilmiş olup; öğrenme stillerinin akademik başarıya etkisini irdeleyen bir kesitini oluşturmaktadır. 


\section{Giriş}

Bireylerin öğrenme kabiliyetine sahip olması, bireyleri diğer canlılardan ayırt eden, toplumsal bir varlık olarak yer almasında en belirgin özelliklerden biri olarak kabul edilmektedir. İnsan, yaşamında gerekli olan davranışları, doğuştan sahip olduğu özellikleri ve çevrenin yaratacağı etkiyle öğrenir (Aşkar ve Akkoyunlu, 1993: 37). Dolayısıyla öğrenme, davranışla ilişki içerisindedir. Davranış ise, organizmanın yaptığı tüm hareketleri tanımlar. Dolayısıyla, organizmanın doğrudan veya dolaylı olarak gözlenebilen her tür hareketi, davranış olarak ifade edilebilir (Seven ve Engin, 2008: 190).

Öğrenme, yaşantılar sonucunda oluşan görece uzun süreli ve kalıcı davranış değişikliği olarak tanımlanmaktadır. Zihinde ve beyinde gerçekleşen ve doğrudan gözlenemeyen bir süreçtir. Fakat gözlenebilir nitelikteki davranış değişiklikleri sayesinde, öğrenmenin varlığına ilişkin güçlü kanıtlara sahip olunmaktadır (Terry, 2007: 41).

Öğrenme yaklaşımında öğrenciler arasında bireysel farklılıkların önemine dayalı olarak çıkan kavram "öğrenme stilidir". Aynı zamanda, öğrenme stillerinin temelinde yer alan bireysel farklılıklar aile, iş ortamı, meslek yaşamı, arkadaş ilişkileri ve eğitim ortamı kişilerin iletişimde içerisinde olduğu birçok alanda kendini göstermektedir (Şeker ve Yılmaz, 2011: 253). Öğrencilerin öğrenme stillerine bağlı olarak genel başarı puanları farklılaşabilir. Bu nedenle, çalışmada; turist rehberliği bölümlerinde okuyan öğrencilerin genel başarı notları üzerinde öğrenme stillerinin etkisi irdelenmektedir.

\section{Kavramsal Çerçeve}

Öğrenme ile ilgili değişik kuramlar, öğrenmeyi farklı biçimde açıklamaktadır. Kimilerine göre öğrenme etki-tepki arasında bağlantı kurmadır, kimilerine göre de bir davranış değişikliğidir (Alkan, 1987: 209). Dolayısıyla bireylerin öğrenme davranışlarını açıklayan çok sayıda kuramdan bahsetmek mümkündür. Öğrenmeyi açıklayan kuramlar; davranışçı, bilişsel yaklaşım ve sosyal öğrenme kuramları yaklaşımı (Baysal ve Tekarslan, 1996: 69; Bacanlı, 2005; Terry, 2007; Ormrod, 2013; Tutar, 2014) olarak sıralanmaktadır.

Bireylerin düşünme, öğrenme şekilleri ve bu süreçlere etki eden unsurların neler olduğunun ortaya çıkarılmasının, etkili öğrenme ve sağlıklı düşünmeyi kolay bir şekle dönüştürmesi beklenmektedir. Bu açıdan, kişilerin nasıl öğrendiği konusunda karşımıza "öğrenme stili" (Güven ve Kürüm, 2006: 76) kavramı çıkmaktadır.

En yalın biçimde öğrenme stili, "öğrenenin öğrenme sürecindeki tercihlerinin tümü" şeklinde ifade edilebilir (Erden ve Altun, 2006: 21). Aynı zamanda bu kavram, geniş çeşitlilikteki öğrenci niteliklerini ve farklılıklarını da içermektedir (Baş ve Beyhan, 2013: 137). Öğrenme stili kavramını, öğrenciler için "ayırt edici ve farklı bir unsur", "bireye özgü", "bireyde farklılık gösteren" olarak ele alan çeşitli tanımlar bulunmaktadır. Keefe (1979), öğrenme stillerini "öğrenenlerin, öğrenme ortamında algılama, karşılıklı etkileme ve tepkide bulunma tarzlarında bir noktaya kadar değişmeyen unsurlar olarak kullandıkları bilişsel, duyuşsal ve psikolojik davranış özellikleri" olarak ifade etmiştir. Dunn (1990) öğrenme stillerini öğrencilerin yeni ve zor bilgiyi öğrenme sürecinde öğrenirken ve anımsarken değişik ve kendilerine ait olan yolları uygulaması şeklinde açıklamıştır. Felder (1996) ise, bilgiyi alma ve işleme sürecinde kişisel yaklaşımda ortaya çıkan farklılıklar olarak tanımlamıştır. 
Dunn ve Dunn (1993: 2) ise öğrenme stilinin, bireylerde farklılık yaratan, yeni ve zor bilgi üzerine odaklanması ile başladığını belirtmiştir. Bilgiyi alma ve zihne yerleştirme süreciyle ilerleyen bir seçim olarak kabul edilmektedir. Fer (2011), öğrenme stilini, "bireyin bir konuyu öğrenme sürecinde tercih ettiği yol, bireye göre öğrenme biçimidir, tarzıdır" şeklinde ifade etmektedir. Della-Dora ve Blanchard'a (1979) göre öğrenme stili, bilgiyi özümserken bireysel olarak tercih edilen yol ve içerikten bağımsız öğrenme süreçlerindeki deneyim olarak ifade edilmektedir. Kayes, Kayes ve Kolb (2005: 334), kişilerin öğrenme sürecinde yapmış oldukları tercihler olarak ifade etmişlerdir.

Öğrenme stilinin bilişsel, duyuşsal ve çevresel yönleri mevcuttur (Cornet, 1983: 72; Guild ve Garger, 1998). Bilişsel öğeler, bilgi işleme yapısının içsel denetimi ile ilişkilidir. Bahsedilen öğeler eğitim ile şekillendirilebilir (Güven ve Kürüm, 2006: 77). Eğer bir stil, bilişsel stil grubu altında yer alıyor ise yetenek ve zekâ ölçümü ile ilgilidir. Örneğin; Riding ve Rayner (2002) öğrenme stilini öğrenme süreci, öğretim tercihi, çalışma süreci ya da bilişsel yetenek olarak alt bölümlere ayırarak bilişsel stil grubu çerçevesinde inceler. Fakat etkinlik odaklı yani öğrenme stili grubu altında yer alıyor ise, yeteneğin kullanımı ile ilgili olarak ifade edilmektedir (Fer, 2011: 203). Duyuşsal ve çevresel öğeler ise, kişilerin seçimine dayanır, ayrıca yetiştirme ve öğretimsel eşleştirme izlemlerine yanıt verir (Açıkgöz, 1996).

Kişilerin bilgiyi farklı şekillerde algıladığı ve işlediği gerçeği, 'Öğrenme Stilleri Kuramı' şeklinde tanımlanan yaklaşımın meydana çıkmasını sağlamıştır. Öğrenme Stilleri Kuramı, bireylerin farklı algılama biçimleri olduğu ve sadece bir stilin tüm kişiler için geçerli olamayacağı savına dayanmaktadır. Fakat kişiler arasındaki algılama farkları, bahsedilen konunun da çeşitli araştırmacılar tarafından farklı şekillerde incelenmesine neden olmuştur (Gülbahar, 2005: 11). Öğrenme stilleri kuramları arasında; Carl Jung'ın (1927) Kişilik Tipleri Teorisi (Keefe ve Ferrell, 1990: 57) ve Myers ve Briggs'in 1962 ve 1975'de gerçekleştirdikleri Kişilik Tipleri Göstergesi (Keefe ve Ferrell, 1990: 57) teorisinin yanı sıra, öğrenme stilleri modellerinden de bahsedilmektedir. Bu modeller arasında Kolb, Gregorc, Jung, Felder ve Silverman, Grasha ve Reichmann, Dunn ve Dunn, McCarthy, Görsel, İşitsel, Kinestetik Öğrenme Stillerinden söz edilmektedir.

Çalışmada görsel, işitsel ve kinestetik öğrenme stili temel alınmıştır. Bu modelde; öğrenme stilleri görsel, işitsel ve kinestetik/dokunsal olarak üç temel özellikte toplanmakta (Felder ve Silverman 1988; Şimşek, 2002; Boydak, 2001; Fleming, 2001; Fleming, 2002; Demir ve Aybek, 2012) ve birçok araştırmacı tarafından kabul edilmektedir (Barbe ve Milone, 1980; Washington, Janosky ve Ann, 1990; Klavas, 1994; Given, 1997; Molden, 2001). Alanyazında bu sınıflama "bilgiyi alma tercihlerine" göre ya da "algısal öğrenme stilleri" şeklinde de ifade edilmektedir (Dunn ve Dunn, 1992; Brown, 2005: 77; Otrar, Gülten ve Özkan, 2012: 306; Bildiren, 2013: 13 ).

Görsel öğrenme stili: Görsel öğrenme stilini baskın olarak kullanan bireyler için, bilginin sözlü veya yazılı metinlerden ziyade resimler, diyagramlar, şemalar, gösteriler vb. görsel araçlarla sağlanması önemlidir (Felder ve Silverman, 1988: 676). Görseller; sınıfta, okuduklarının altını çizerler, değişik renkler, semboller ve kartlar kullanarak, sayfa düzenlemesini tercih ederler (Bilasa, 2012: 11). Çalışırken, çeşitli şekillerde görüntüleri yeniden oluştururlar, stratejiler kullanırlar, sayfaları zihinden yeniden biçimlendirirler, sözcükleri sembollerle ifade ederler. Sınav sürecinde, sayfalardaki resimleri hatırlayarak, çizerler, grafikler oluştururlar, görsel olayları kelimelerle ifade ederler (Fleming, 1995: 2; Picard, 2000: 17-18); duyduklarından anlam çıkarmakta sıkıntı yaşarlar. Çoğunlukla imla hatası yaparlar. Okumaktan 
hoşlanmazlar, yaşadıkları ortamın durumunu umursamayarak, hareket edip bedenleri aracılığı ile tepki verirler (Boydak, 2001: 73).

İşitsel öğrenme stili: İşitsel öğrenme stili baskın bireyler, sözlü ve yazılı metinleri, betimlemeleri tercih ederler (Reid, 1987: 89; Felder ve Silverman, 1988:676677), duyma organlarını daha rahat kullanırlar (Fleming, 1995:1; Erden ve Altun, 2006: 23). Sözel faaliyet ve uygulamalarda daha üstün olup yüksek ses tonuyla okumayı tercih ederler, tartışma yoluyla iletişim kurarlar, az not alırlar ve notlar hakkında konuşarak çalışmayı tercih ederler (Picard, 2000: 14-16). İşitseller; sınıfta, derslerde aktiftirler. Diğer öğrencilerle konuları tartışarak, yeni fikirlerini insanlarla paylaşırlar (Picard 2000: 17-18). Konuşmaktan ve konuşulanı dinlemekten hoşlanırlar (Şimşek, 2002: 36).

Kinestetik öğrenme stili: Bu stili uygulayan bireyler, bahsedilen konuyu en iyi kendileri yaptıklarında öğrenirler (Felder ve Henriques, 1995). Dokunma duyularını daha rahat kullanırlar (Erden ve Altun, 2006: 23). Kısa süreli ve sık mola almayı tercih ederler, uzun süreli okumalarda yerinde duramazlar, her şeyi ve fiziksel olayları hatırlarlar, işitsel ve görsel açıklamalarda dikkatleri dağınıklık gösterir (Picard, 2000: 14-16). Sınıfta, tüm duyularını kullanırlar (Fleming, 1995: 2) çalışma sahalarına gezi düzenlerler, deneme-yanılma yöntemini tercih ederler, gerçek yaşam olaylarını dinlerler, el becerilerine dönük işler gerçekleştirirler. Çalışırken, not tutmazlar, notlarını özetlerken örnekleri kullanmayı tercih ederler, örnekleme sürecinde resim ve fotoğraf kullanırlar, notları hakkında başka kinestetik bireye bilgi verirler. Sınav süresince, çalışırken belirlediği cevaplarını yazarlar, rol oynamayla sınav olmayı tercih ederler (Picard, 2000: 17-18).

Farklı öğrenme stillerini kullananlar arasında; görseller görme, işitseller duyma organlarını; kinestetikler ise dokunma duyularını çoğunlukla rahatıkla kullanırlar (Bedir ve Akkurt, 2014: 190). Öğrenciler biri baskın olmak üzere üç tarzı birlikte de kullanabilirler (Erden ve Altun, 2006: 23).

Bireylerin ve/veya öğrencilerin öğrenme stillerini belirlemeye dönük çok sayıda araştırmaya rastlamak mümkündür. Farklı yazarlar tarafından öğrenme stillerinin farklı ölçeklerle belirlenmesi ve boyutlarının farklı adlandırılması nedeniyle, literatürde (Marriot, 2002; Barron, 2002; Lashley ve Barron, 2006; Watson, McGuire ve Barron 2006; Tuna, 2008; Azizoğlu ve Çetin, 2009; Bahar, 2009; Çiğdem ve Memiş, 2011; Şeker ve Yılmaz, 2011; Lun Su, 2012; Çalışkan ve Kılınç, 2012; Jahanbakhsh, 2012; Seven, Bağcivan, Kılıç ve Açıkel, 2012; Cranage, Lambert, Morais ve Lane, 2013; Balcı ve Sünbül, 2015; Işıldar, Aktaş ve Kurgun,2016) oldukça farklı çalışmalara rastlanmaktadır.

\section{Amaç}

Araştırmanın amacı, öğrenme stillerinin akademik başarıya etkisini ortaya koymaktır. $\mathrm{Bu}$ çerçevede, öğrencilerin öğrenme stillerinin sınıflara ve cinsiyete göre farklılık gösterip göstermediği irdelenecek ve aşağıdaki hipotez test edilecektir.

Farklı öğrenme stilleri, öğrencilerin akademik başarılarına yansıyabilir. Yapılan araştırmalarda; öğrenme stilinin başarıyı belirleyen bir etken olduğu (Aşkın, 2006; Karakış, 2006; Süral, 2008), akademik başarı ile öğrenme stili arasından olumlu yönde bir ilişki bulunduğu (Bilgin ve Durmuş, 2003), akademik başarının öğrenme stillerine göre farklılık gösterdiği (Kaya, Boazaslan ve Durdukoç, 2012; Jahanbakhsh, 2012; Baş ve Beyhan, 2013; Siddique, Abbaz, Riaz ve Nazir, 2014) ortaya çıkmıştır. Dolayısıyla, 
turizm rehberliği bölümlerinde okumakta olan öğrencilerin baskın olarak kullandıkları öğrenme stilinin, akademik başarılarını etkileyebileceği iddiasında bulunulabilir.

$\mathrm{H}$ : Turizm rehberliği öğrencilerinin öğrenme stilleri, akademik başarılarını etkiler.

\section{Araştırmanın Yöntemi}

Tanımlayıcı türde tasarlanan araştırmada veriler, literatüre dayalı geliştirilen bir anket ile toplanmıştır. Öğrencilerin öğrenme stilleri Gökdağ (2004) tarafından geliştirilen Öğrenme Stilleri Ölçeği ile belirlenmiştir (Eskici, 2008). 28 maddeli ölçeğin 13 maddesi görsel, 10 maddesi kinestetik ve 5 maddesi işitsel öğrenme stilini ölçmektedir. Ölçek maddelerinin tepki kategorileri 5 'li Likert $(1:$ Kesinlikle katılmıyorum,.., 5:Kesinlikle katılıyorum) derecelemesine tabi tutulmuştur.

Ana kitle, Türkiye'deki üniversitelerde turizm rehberliği eğitimi alan öğrenciler oluşturmakla birlikte, örnekleme çerçevesi, lisans düzeyinde turizm rehberliği eğitimi alan ve 2016-2017 eğitim-öğretim yılında kayıt yenileyen öğrenciler olarak tanımlanmıştır. Bu eğitim öğretim yılında 11 akademik birimde toplam 2406 öğrenci bulunmaktadır. $\% 5$ anlam düzeyinde, Varyansı maksimum kılan oran $(p=0,5)$ ve $\% 3$ örnekleme hatası esas alınarak örnek büyüklüğü 739 olarak belirlenmiştir. Örnek büyüklüğü 850'ye çıkarılarak, çalışma evreni içindeki oranları dikkate alınarak sınıf ve cinsiyet bazında kotalar belirlenmiştir.

Anket, öğrencilere, söz konusu eğitim-öğretim yılının bahar yarıyılında, turizm rehberliği bölümlerinde görevli öğretim elemanlarının yardımıyla yüz yüze uygulanmıştır. İzin alınabilen 10 üniversite toplamda 1115 anket sayısına ulaşılmıştır. Ölçek maddelerinin tamamının yanıtlandığı görülmekle birlikte; çoklu sapan analizi sonucu 10 gözlemin veri setinden çıkarılmasına karar verilmiştir. Dolayısıyla, 1105 anket üzerinden analizler gerçekleştirilmiştir. Elde edilen 1105 anket, araştırmanın evreni dikkate alındığında, evreni (1105/2406) \%45,9 oranında temsil ettiği görülmektedir. Bir üniversitede anketin uygulanamamasını da dikkate alırsak, evreni temsil oranı (1105/2259) \%48,9'a yükselmektedir.

Öğrenme stilleri ölçeğinin güvenirlik analizinde, Alfa katsayısı 0,827 olarak bulunmuştur. Madde-bütün korelasyonu $+0,200$ 'ün altında düşük olan üç madde ölçekten çıkarılmıştır. Geriye kalan 25 maddenin Alfa katsayısı 0,835 ve madde-bütün korelasyon aralığı da 0,200-0,571 olarak bulunmuştur. Dolayısıyla verinin güvenilir olduğunu söylemek mümkündür. Daha sonra, görsel, kinestetik ve işitsel öğrenme stillerinin puanları toplanarak ortalamaları alınmış ve regresyon analizlerinde kullanılmıştır. Analizlerde; tanımlayıcı istatistiklerin yanı sıra, bağımsız örneklem t-testi ve tek yönlü varyans analizinden yararlanılmıştır.

\section{Bulgular}

Araştırmaya katılan 1105 turizm rehberliği bölümü öğrencilerinin \%50,3'ü erkek, \%49,7'si kadın öğrencilerden oluşmaktadır. \%74,6'sı birinci öğretim, \%25,4'ü ikinci öğretim öğrencilerdir. Öğrencilerin \%38,6'sı 1.sınıf, \%24,4'ü 2.sınıf, \%22,5'i 3.sınıf, $\% 14,4$ 'ü 4.sınıfta öğrenim görmektedirler.

Tablo 1, sınıflara göre öğrenme stillerinin karşılaştırımasını ortaya koymaktadır. İşitsel öğrenme stili bakımından, sınıflar arasında herhangi bir anlamlı farklılık tespit edilemez iken, görsel ve kinestetik öğrenme stili bakımından anlamlı farklılıklar söz konusudur. Görsel öğrenme stili bakımından göreceli olarak en büyük ortalama 3. ve 4. sınıf öğrencilerine aittir. İstatistiksel anlamda farklılık ise, 3. sınıflar ile 1. ve 2.sınıflar 
arasındadır. Ortalamanın yıllar içinde yükselmesi, öğrencilerin zaman geçtikçe görsel öğrenme stillerinin daha önemli hale geldiği izlenimi edinilmektedir.

Kinestetik öğrenme stili bakımından yine en yüksek ortalama göreceli olarak 3 . ve 4. sınıf öğrencilerine aittir. İstatistiksel açıdan farklııı da 1.sınıflarla 3. ve 4. sınıf öğrencileri arasındadır. Dolayısıyla zaman geçtikçe öğrencilerin kinestetik öğrenme stiline daha fazla ağırlık verdikleri anlaşılmaktadır.

İşitsel öğrenme stilinin kullanımı bakımından sınıflar arasında anlamlı bir farklılık yoktur. Bu durum, sınıflara göre değişmeyen stilin, işitsel öğrenme stili olduğunu ortaya koymaktadır. Dolayısıyla tüm öğrencilerin duyma organlarını benzer şekilde kullandıkları söylenebilir.

Tablo 1: Öğrenme Stillerinin Sınıflara Göre Karşılaştırılması

\begin{tabular}{|c|c|c|c|c|c|c|}
\hline & Sinıf & $\mathbf{N}$ & Ort. & S.Sapma & $\begin{array}{c}F_{(3 ; 101)} \\
p \text { değeri }\end{array}$ & Farklılık \\
\hline \multirow{5}{*}{$\begin{array}{l}\text { Görsel } \\
\text { öğrenme stili }\end{array}$} & 1.sinıf & 427 & 3,4731 & 0,62580 & \multirow{5}{*}{$\begin{array}{c}2,827 \\
\mathrm{p}: 0,038\end{array}$} & \multirow{5}{*}{$\begin{array}{l}1<3 \\
2<3\end{array}$} \\
\hline & 2.sınıf & 270 & 3,4729 & 0,63328 & & \\
\hline & 3.sinıf & 249 & 3,5839 & 0,56120 & & \\
\hline & 4.sinif & 159 & 3,5820 & 0,57580 & & \\
\hline & Toplam & 1105 & 3,5137 & 0,60816 & & \\
\hline \multirow{5}{*}{$\begin{array}{l}\text { Kinestetik } \\
\text { öğrenme stili }\end{array}$} & 1.sınıf & 427 & 3,5237 & 0,65395 & \multirow{5}{*}{$\begin{array}{c}2,876 \\
\text { p: } 0,035\end{array}$} & \multirow{5}{*}{$\begin{array}{l}1<3 \\
1<4\end{array}$} \\
\hline & $2 . \sin I f$ & 270 & 3,5731 & 0,65222 & & \\
\hline & 3.sınıf & 249 & 3,6506 & 0,59200 & & \\
\hline & 4.sınıf & 159 & 3,6502 & 0,55168 & & \\
\hline & Total & 1105 & 3,5826 & 0,62771 & & \\
\hline \multirow{5}{*}{$\begin{array}{l}\text { İşitsel } \\
\text { öğrenme stili }\end{array}$} & 1.sinıf & 427 & 3,2728 & 0,85300 & \multirow{5}{*}{$\begin{array}{c}0,395 \\
\mathrm{p}: 0,757\end{array}$} & \multirow{5}{*}{ Yok } \\
\hline & 2.sınıf & 270 & 3,2741 & 0,78844 & & \\
\hline & 3.sınIf & 249 & 3,2249 & 0,81265 & & \\
\hline & $4 . \sin I f$ & 159 & 3,2091 & 0,77228 & & \\
\hline & Total & 1105 & 3,2532 & 0,81649 & & \\
\hline
\end{tabular}

Tablo 2, öğrenme stillerinin cinsiyete göre karşılaştırmasını göstermektedir. Kadın öğrencilerin erkeklere göre görsel ve kinestetik öğrenme stilini daha çok kullandıkları anlaşılmaktadır. İşitsel öğrenme stili bakımından kadın ve erkek öğrenciler arasında anlamlı bir farklılık bulunmamaktadır.

Tablo 2: Öğrenme Stillerinin Cinsiyete Göre Karşılaştırılması

\begin{tabular}{|c|c|c|c|c|c|}
\hline & Cinsiyet & $\mathbf{N}$ & Ortalama & S.Sapma & t-değeri \\
\hline \multirow{2}{*}{$\begin{array}{c}\text { Görsel öğrenme } \\
\text { stili }\end{array}$} & Erkek & 549 & 3,4331 & 0,61666 & $-4,413$ \\
\cline { 2 - 5 } & Kadın & 556 & 3,5932 & 0,58947 & $\mathrm{p}<0,001$ \\
\hline Kinestetik & Erkek & 549 & 3,5301 & 0,64631 & $-2,772$ \\
\cline { 2 - 5 } öğrenme stili & Kadın & 556 & 3,6344 & 0,60490 & $\mathrm{p}: 0,006$ \\
\hline \multirow{2}{*}{$\begin{array}{c}\text { Iş̧itsel öğrenme } \\
\text { stili }\end{array}$} & Erkek & 549 & 3,2322 & 0,81334 & $-0,847$ \\
\cline { 2 - 4 } & Kadın & 556 & 3,2738 & 0,81980 & $\mathrm{p}: 0,397$ \\
\hline
\end{tabular}

Öğrencilerin öğrenme stillerinin akademik başarı puanlarına etkisini görmek için çoklu regresyon analizi yapılmıştır (Tablo 3). Analiz sonuçları sınıf bazında öğrenme stillerinin genel başarı puanı üzerinde farklı şekillerde etkili olduğunu ortaya koymaktadır. Birinci sınıfların genel başarı puanı üzerinde herhangi bir öğrenme stilinin etkisi bulunmamaktadır. Bununla birlikte ikinci $(\beta: 0,321)$ ve dördüncü sınıfların ( $\beta$ : 
0,287), başarı puanları üzerinde görsel öğrenme stilinin anlamlı bir etkisi bulunmaktadır.

Öğrenme stillerinin üçüncü sınıfların genel başarı puanı üzerindeki etkisinde ilginç bir durumla karşılaşılmaktadır. Görsel öğrenme stilinin üçüncü sınıflarda $\alpha: 0,10$ düzeyinde anlamlı bir etkisi $(\beta$ : 0,147$)$ olduğu tespit edilmekle birlikte, bu sınıfta işitsel öğrenme stilinin başarı puanı üzerinde olumsuz bir etki $(\beta:-0,181)$ yarattığı ortaya çıkmaktadır.

Sınıf ayrımı yapılmadan yapılan analizde; üç öğrenme stilinden sadece görsel öğrenme stilinin $(\beta$ : 0,173$)$, genel başarı puanını anlamlı şekilde etkilediğini ortaya koymaktadır. Öğrenme stillerinden görsel öğrenme stilinin, başarı puanı üzerinde belirleyici olduğunu da söylemek mümkündür. Dolayısıyla ortaya atılan hipotezin, mevcut verilerle kısmen desteklendiği söylenebilir.

Tablo 3: Öğrenme Stillerinin Başarı Puanına Etkisi

\begin{tabular}{|c|c|c|c|c|c|}
\hline & tandardiz & Imiş $\beta$ k & yıları & & \\
\hline Bağımsız değişkenler & GFNFI & & SII & & \\
\hline ÖĞRENME STÍLI & GEINEL & 1.sınıf & 2.sınıf & 3.sınıf & 4.sınıf \\
\hline Görsel & $0,173^{* * *}$ & 0,024 & $0,321^{* * *}$ & 0,147 & $0,287^{* \star}$ \\
\hline Kinestetik & 0,022 & 0,080 & $-0,029$ & $-0,024$ & $-0,026$ \\
\hline Işitsel & $-0,057$ & 0,017 & 0,004 & $-0,181^{*}$ & $-0,099$ \\
\hline Model F & $8,791^{* * *}$ & 1,053 & $6,953^{\star * *}$ & $3,153^{*}$ & $3,388^{*}$ \\
\hline $\mathbf{R}$ & 0,175 & 0,105 & 0,305 & 0,212 & 0,269 \\
\hline Düzeltilmiş $\mathbf{R}^{2}$ & $\% 2,7$ & $\% 01$ & $\% 7,9$ & $\% 3,1$ & $\% 5,1$ \\
\hline En düşük tolerans & 0,632 & 0,643 & 0,550 & 0,656 & 0,672 \\
\hline En büyük VíF & 1,582 & 1,555 & 1,819 & 1,525 & 1,489 \\
\hline En büyük Cl & 17,818 & 16,903 & 18,427 & 18,447 & 20,354 \\
\hline & en: & $\begin{array}{l}\text { kgene } \\
; ; * * \star\end{array}$ & $\begin{array}{l}\text { puani; } N \\
0<0,05\end{array}$ & rudan & \\
\hline
\end{tabular}

\section{Sonuç ve Öneriler}

Her bireyin öğrenme süreci ve stili farklıdır. Öğrenme stillerindeki tercihler bireylerin bilgiye hızlı ve kolay ulaşımını sağlayabilmektedir. Lisans düzeyinde turizm rehberliği eğitimi alan öğrencilerin kullandıkları öğrenme stillerinin akademik başarı puanlarına etkisini irdelendiği bu çalışmada; 2016-2017 eğitim öğretim yılı bahar yarıyılında kayıt yenileme işlemi yapan lisans düzeyinde turizm rehberliği eğitimi alan 1105 öğrenciden elde edilen veriler kullanılmıştır.

Bulgular, lisans düzeyinde turizm rehberliği eğitimi alan öğrencilerin çoğunluğunun, "görsel öğrenme stilini" tercih ettikleri yönündedir. Bu durum, öğrencilerin bilgileri görsel şekilde kodlamayı tercih ettiğini, çoğunlukla gördüklerini hatırladıkları, sözlü uyarıcılardan ziyade, görselleştirmeye yönelik öğrenme stratejilerini kullanmaya yatkın olduklarını göstermektedir (Veznedaroğlu ve Özgür, 2005: 12). Alanyazında, Ewing ve Yong (1993), Wallace (1995), Bilasa (2012), Bildiren (2013), Cranage ve diğ., (2013), Yılmaz, Metin, Birişçi ve Coşkun (2010) öğrencilerin farklı öğrenme stilleri tercihlerine sahip olsalar da, tümünün görsel öğrenme stilinde baskın olduklarını belirtmişlerdir. Bu bağlamda bu araştırma sonucunun mevcut alan yazın ile benzerlik gösterdiği söylenebilir. 
İşitsel öğrenme stili tercihlerinde sınıflara göre bir farklılık olmadığı görülmektedir. Bu sonuç, Park'ın (1997) öğrenci grupları arasındaki öğrenme stili tercihlerini incelediği araştırması ile benzerlik göstermektedir. Turizm rehberliği öğrencilerinde; kinestetik öğrenme stilini sınıf düzeyi arttıkça daha fazla tercih edildiği görülmektedir. Bu durum, öğrencilerin zaman geçtikçe kinestetik öğrenme stiline sıcak baktığı, öğrenme sürecinde kendi kendilerine gerçekleştirdikleri, fakat tüm duyularını kullandıkları şeklinde açıklanabilir. Kinestetik öğrenme sürecinde bireyler hareket etme, ilişki kurma ve öğrenirken aktif birşeyler (Veznedaroğlu ve Özgür, 2005: 12) yapma isteğindedirler. Dolayısıyla bu durum, sınıf düzeyi arttıkça öğrencilerin görsel ve işitselden uzaklaşıp; daha çok fiilen, yaparak, deneyerek öğrenme isteğinde olduklarını göstermektedir. Kinestetik öğrenenler aktif öğrenenler grubunda yer aldıkları için, etkileşimi tercih ederler. Turizm rehberliği öğrencilerinin de meslek alanlarının en temel öğesinin "güçlü ve etkili iletişim olması" zamanla bu öğrenme tercihinde bulunmalarında etkili olabilmektedir. Stevens, Kitterlin ve Tanner (2012), çalışmalarında turizm alanında eğitim alan öğrencilerin kinestetik öğrenme stilini tercih ettiklerini belirtmiştir. Işıldar ve diğ., (2016), ön lisans 2.sınıf öğrencilerinin 1.sınıf öğrencilerine oranla kinestetik öğrenme stilini tercih ettiğini ifade etmiştir. Dolayısıyla elde edilen bulguların alanyazın ile paralellik gösterdiği ifade edilebilir.

Cinsiyetler açısından öğrenme stili tercihlerinde kadınlarda görsel; erkeklerde ise kinestetik öğrenme stilinin baskın olduğu görülmektedir. İşitsel öğrenme stilinde ise istatiksel olarak anlamlı bir farklılık söz konusu değildir. Cinsiyete göre öğrenme stillerinin farklılık gösterdiğini belirten (Ergür, 2000; Çaycı ve Ünal, 2007, Almuran, 2008; Lun Su, 2012; Bilasa, 2012;Ekici, 2013; Taş ve Erdem, 2013, Siddique ve diğ,. 2014) çeşitli çalışmalar da yer almaktadır.

Lisans düzeyinde turizm rehberliği eğitimi alan öğrencilerinde; görsel öğrenme stilinin genel akademik başarı puanı üzerinde olumlu bir etkisi olduğu ortaya çıkmaktadır. Sınıflar bazında incelendiğinde, 1. sınıf turizm rehberliği öğrencilerinin öğrenme stillerinin genel akademik başarı puanlarına bir etki yapmadığı görülmektedir. 2., 3. ve 4., sınıf öğrencilerin görsel öğrenme tercihlerinin genel başarı puanlarını etkilediği ortaya çıkmıştır. Buna rağmen işitsel öğrenme stilini tercih eden 3 . sınıf düzeyindeki öğrencilerin ise genel başarı puanlarının olumsuz etkilendiği görülmektedir. İşitsel öğrenenlerin sınıf düzeyi arttıkça, ders süreçlerinde dinlemekten daha çok aktif bir öğrenme sürecine yöneldikleri ifade edebilir. Hızlı iletişim, internet ve sosyal medya ağlarının artması ve öğrencilerin zamanlarının büyük bir kısmını teknoloji odaklı yaşamaları, doğal olarak "sadece dinlemekten sıkılan" bireylerin oluşmasına yol açmış olabilir. Jahanbakhsh (2012) çalışmasında; görsel öğrenme stili ile akademik başarı arasında anlamlı bir ilişki saptamıştır. Stevens ve diğ., (2012), turizm eğitimi alan öğrencilerin akademik başarılarında öğrenme stillerinin önemli bir etkisi olduğunu ifade etmiştir. Siddique ve diğ.,(2014) öğrencilerin akademik başarıları ile görsel, işitsel ve kinestetik öğrenme stillerinde anlamlı bir farklılık olduğunu belirtmiştir.

Alan yazınında, öğrenme stillerinin, akademik başarı üzerinde etkili olduğunu belirten çalışmalara (Koçak, 2002; Gökdağ, 2004; Emamepur ve Shams, 2004; Bengiç, 2008; Yurtseven, 2010; Çiğdem ve Memiş, 2011; Jahanbakhsh, 2012) rastlanmaktadır. Buna karşın, Kılıç ve Karadeniz (2004) ve Topuz ve Karamustafaoğlu (2013), çalışmalarında akademik başarı ve öğrenme stilleri arasında anlamlı bir ilişki olmadığını ifade etmişlerdir. Seven ve diğ., (2012) öğrenme stillerinin akademik başarılarını etkilemediğini belirtmişlerdir.

Beceren (2004), öğrencilerin öğrenme stillerine uyum gösteren bir şekilde yapılan öğretimin öğrencilerin akademik başarılarına anlamlı katkılar yaptığını 
belirtmiştir. Baş ve Beyhan (2013) öğrenme stillerine dayalı olarak yapılan öğretimin öğrencilerin akademik başarıları, derse dönük tutumları ve öğrenilenlerin kalıcılığında pozitif gelişmeler sağladığını belirlemişlerdir.

Öğrenmenin bir intiyaç olarak incelemeye alınması akademik başarının artışı ile anlamlı düzeyde ilişkilidir (Yazıcı ve Altun, 2013: 1248). Öğrenciler, genellikle bir öğrenme stilinde baskın olsa da diğer öğrenme stillerinin özelliklerini de belirli oranda gösterirler (Bilgin ve Durmuş, 2003: 392). Kendi öğrenme stiline uyumlu bir öğrenme ortamında öğrencilerin daha etkin ve öğrenmeye daha hevesli oldukları görülmektedir. Dolayısıyla, akademik başarıları daha yüksek seviyeye ulaşmakta ve öğrenilenler de daha kalıcı bir şekle dönüşmektedir (Baş ve Beyhan, 2013: 150). Bu açıdan çalışma kapsamında aşağıda bazı öneriler geliştirilmiştir.

- Lisans düzeyinde turizm rehberliği eğitimi alan öğrencilerin öğrenme stillerinin öğretim elemanları tarafından bilinmesi ve öğrencilerin öğrenme stillerine uygun öğrenme ortamları oluşturulmalı.

- Öğrencilere ders süresi dışında da farklı fırsatlar verilmeli, kendilerini gerçekleştirmelerinde öğrenme stillerinin önemi dikkate alınmalı, bireysel ve grup şeklinde çalışmalarına imkân verilmelidir (Şeker ve Yılmaz, 2011: 263).

- Öğrenme stillerinin sınıf düzeylerine göre değişiklik göstermesi ve öğrenme sürecinde değişim ve gelişmeye gidilmesi için, öğrenim süresi boyunca farklı zamanlarda öğrenme stilleri envanterleri uygulanarak, öğrenme stilleri belirlenmeye çalışılmalıdır.

- Öğrenme stilleri dikkate alınarak, oluşturulacak farklı öğrenme ortamları gerekli araç ve gereçlerle desteklenmeli ve böylece başarı puanlarının artması sağlanabilir.

- Sadece öğrenme ortamları ve stillerinin belirlenmesi ile değil, aynı zamanda, üniversitelerde ders veren öğretim elemanlarının da çeşitli seminer ve hizmet içi eğitimlere katılarak farklı öğrenme stillerine en iyi nasıl hizmet edilebileceğini öğrenmeleri teşvik edilebilir. Böylece eğitimöğretim süreçlerinde daha etkin olmaları sağlanabilir.

- Kinestetik öğrenme stilinin sınıf düzeyi arttıkça artması, öğretim elemanlarının bu öğrenme stiline yakın olarak not tutmaktan ziyade, bilginin tartışıldığı ve uygulandığı ortamlar yaratması (Veznederoğlu ve Özgür, 2005: 14) ile daha etkin hale getirilebilir. Arkeoloji, sanat tarihi vb. derslerin öğretim elemanları uygulama gezilerinin düzenlenmesinde aktif olarak yer alarak ve onlara görev vererek öğrencilere uygun ortamın sağlanmasına katkı sağlayabilmelidir.

- Öğretim elemanları kinestetik öğrenenlere yönelik olarak, sınıf içerisinde öğrencilerin gruplar oluşturmasını sağlayarak birlikte düşünme, tartışma ve sorun çözebilme yetkinliğine kavuşmalarına destek olabilirler. Çünkü kinestetik öğrenenler, akranlarıyla öğrenmeyi isteyen tiplerdir (Dunn ve Griggs, 2003)

- İşitsel öğrenenlerin genel başarı puanlarının düşmesini engellemeye yönelik olarak öğretim elemanları görsel ve kinestetik öğrenme stillerinin de ders süreçlerinde yer almasına katkı sağlayabilirler. Farklı öğrenme stillerini uyumlaştırıcı etkinlikler düzenleyip öğrenme sürecini destekleyebilirler.

- Turizm rehberliği öğrencileri ile ilgili olarak, çalışma alanlarına gezi düzenleyerek, deneme-yanılma yöntemini kullanarak gerçek yaşam olaylarını dinleyerek, el becerilerine dönük işler yapılmalıdır. 
- Turizm Rehberliği bölümünde verilen derslere yönelik olarak, bölüm başkanları ve öğretim elemanları belirlenen üç öğrenme stilini de kapsayacak aktive ve organizasyonlarla ders içeriklerinin yapılandırılmasına çalışmalıdır.

\section{Kaynakça}

Alkan, C. (1987). Öğrenme- öğretme süreçleri ilkeler. Ankara Üniversitesi Eğitim Bilimleri Fakültesi Dergisi, 20(1), 209-229.

Aşkar, P., ve Akkoyunlu, B. (1993). Kolb öğrenme stili envanteri. Eğitim ve bilim, 87 (17), 37-47.

http://www.egitimvebilim.ted.org.tr/index.php/EB/article/download/5854/1987 (7 0cak 2016)

Aşkın, Ö. (2006). Öğrenme Stilleri İle İlgili Elektronik Ortamda Yayımlanan Çalışmaların İncelenmesi. Yayınlanmamış Yüksek Lisans Tezi. Ankara Üniversitesi, Ankara

Azizoğlu, N., ve Çetin, G. (2009). 6. ve 7. sınıf öğrencilerin öğrenme stilleri, fen dersine yönelik tutumları ve motivasyonları. Kastamonu Eğitim Dergisi, 17(1), 171- 182

Bacanlı, H. (2005). Gelişim ve öğrenme. Ankara: Nobel Yayın Evi.

Bahar, M. (2009). The relationships between pupils' learning styles and their performance in mini science projects. Kuram ve Uygulamada Eğitim Bilimleri, 9(1), 31-49.

Barbe, W. B., ve Milone, Jr. M. N. (1980). What we know about modality strengths. EducationalLidership,378-380 http://www.ascd.org/ASCD/pdf/journals/ed_lead/el_198102_barbe.pdf Haziran 2016).

Barron, P. E. (2002). Providing a more successful education experience for Asian hospitality management students studying in Australia: A focus on learning styles. Journal of Teaching in Travel and Tourism, 2(2), 63-88.

Balcı, Ö., ve Sünbül, A. M. (2015). İngilizce okuma derslerinde öğrenme stillerine dayalı etkinliklerle ilgili öğrenci görüşleri. SDU International Journal of Educational Studies, 2(1), 1-9.

Baş, G., ve Beyhan, Ö. (2013). Öğrenme stillerine dayalı öğretimin akademik başarı, kalıcılık ve ingilizce dersine yönelik tutumlara etkileri. Ankara University Journal of Faculty of Educational Sciences, 46(2), 133-158.

Baysal, C., ve Tekarslan, E. (1996). İşletmeciler için davranış bilimleri. İstanbul: Avcıol Basım.

Beceren, S. (2004). An investigation into the impact of matched learning and teaching styles on student success in ELT prep classes. Yayımlanmamış yüksek lisans tezi, Çanakkale On Sekiz Mart Üniversitesi Sosyal Bilimler Enstitüsü, Çanakkale

Bedir, G., ve Akkurt, A. (2014). Sosyal bilgiler öğretmenliği öğrencilerinin algısal öğrenme stil tercihlerinin genel akademik ve coğrafya ders başarısına etkisi (Gaziossmanpaşa Üniversitesi Örneği). Atatürk Üniversitesi Sosyal Bilimler Enstitüsü Dergisi, 18(1), 189-201

Bengiç, G. (2008). The relationship between 6 th and 7 th grade primary school student's learning styles and achievement in social studies course. Unpublished master thesis. Pamukkale University, Denizli.

Bilasa, P. (2012). Üniversite öğrencilerinin öğrenme stillerinin belirlenmesi (Gazi Üniversitesi Örneği). ODÜ Sosyal Bilimler Araştırmaları Dergisi, 3(9), 7- 20.

Bilgin, İ., ve Durmuş, S. (2003). Öğrenme stilleri ve öğrenci başarası arasındaki ilişki üzerine karşılaştırmalı bir araştırma. Kuram ve Uygulamada Eğitim Bilimleri, 3(2), 381-400. 
Bildiren, A. (2013). Examining of learning styles of gifted students. Journal of Gifted Education Research, 1(1), 10- 21.

Boydak, A. (2001). Öğrenme stilleri. İstanbul: Beyaz yayınları

Çalışkan, H., ve Kılınç, G. (2012). The relationship between the learning styles of students and their attitudes towards social course. Social and Behavioral Sciences. 55,47-56.

Çiğdem, G., ve Memiş, A. (2011). Sınıf öğretmenliği adaylarının öğrenme stilleri ve öğretmenlik mesleğine yönelik tutumlarının çeşitli değişkenler açısından incelenmesi. Çukurova Üniversitesi Eğitim Fakültesi Dergisi, 3(40), 57-77.

Cornet, C. E. (1983). What you should know about teaching and learning styles. Bloomington. IND: Phi Delta Kappa Education Foundation

Cranage, D., Lambert, C. U , Morais, D., ve Lane, J.L. (2006). The influence of learning style on hospitality and tourism students' preference for web assignments. Journal of Hospitality \& Tourism Education, 18(4), 18-26.

Çiğdem, G., ve Memiş, A. (2011). Sınıf öğretmenliği adaylarının öğrenme stilleri ve öğretmenlik mesleğine yönelik tutumlarının çeşitli değişkenler açısından incelenmesi. Çukurova Üniversitesi Eğitim Fakültesi Dergisi, 3(40), 57-77.

Della-Dora, D., and Blanchard, L. J. (1979). Moving toward self-directed learning: Highlights of relevant research and promising practice. Alexandria, VA: Association for Supervision and Curriculum Development.

Demir, R., ve Aybek, B. (2012). Dokuzuncu sınıf öğrencilerinin öğrenme stilleri ve çoklu zekâ alanlarının incelenmesi. Uluslararası Eğitim Programları ve Öğretim çalışmaları Dergisi, 2(4), 27- 40.

Dunn, R. (1990). Rita Dunn answers questions on learning styles. Educational Leadership, 48 (2): 15-19.

Dunn R., ve Dunn K. (1992). Teaching elemantary students through their indivual learning styles: Boston:Allyn \& Bacon.

Dunn, R., ve Dunn, K. (1993). Teaching secondary students through their individual learning styles. USA.

Dunn R. ve Griggs S. (2003). The Dunn and Dunn Learning Style Model and its Theoretical Cornerstone. In: Synthesis of the Dunn and Dunn Learning Styles Model Research: Who, What, When, Where, and So What. St. John's Univ. Center for the Study of Learning and Teaching Styles. New York, 1- 6.

Emamepur, S. Shams, H. (2004). Study of learning styles in students of university and their relationship with academic achievement and gender. PsychologicaleducationalResearches quarterly of Tarbiyat moalem, 5,1-24

Erden, M., ve Altun, S.(2006). Öğrenme stilleri. İstanbul: Morpa Yayınevi.

Eskici, M. (2008). Öğrencilerin Öğrenme Stilleri İle Akademik Başarıları ve Cinsiyet Arasındaki İlişki. Yüksek Lisans Tezi, Trakya Üniversitesi Sosyal Bilimler Enstitüsü

Ewing, N.J., ve Yong, L.F. (1993). Learning style preferences of gifted minority students. Gifted Education International, 9 (1), 40-44.

Felder, R.M., ve Silverman, L. (1988). Learning and teaching styles in engineering education. Engineering Education, 78(7), 674-681.

Felder, R. M., ve Henriques, E. R. (1995). Learning and teaching styles in foreign and second language education. Foreing Language Annals, 28 (1), 21-31.

Felder, R. M. (1996) Matters of Style, ASSE Prism, North Carolina State University,6(4),18- 23, http://www4.ncsu.edu/unity/lockers/users/f/felder/public/Papers/LS- $\quad(10$ Ekim 2016)

Fer, S. (2011). Öğrenme stilleri ve stil odaklı öğretim tasarımı. Fer, S. (Ed.) Öğrenme Öğretme Kuram ve Yaklaşımları içinde(ss.200-215). Ankara: Anı Yayıncılık 
Fleming, N. D. (1995). I'm different; not dumb. Modes of presentation (VARK) in the tertiary classroom. A. Zelmer (Ed.), Research and Development in Higher Education, Proceedings of the 1995 Annual Conference of the Higher Education and Research Development Society of Australasia (HERDSA), HERDSA, 18: 308 - 313

Fleming, N. D. (2001). Teaching and Learning Styles: VARK Strategies. Published by the Author.

Fleming, N.D. (2002). Learning to Make a Difference: VARK Preferences, Published by the Author.

Given, B. K. (1997). How to deal with difficult principals: a learning styles approach. The Clearing House, 70(5), 257-260.

Gökdağ, M. (2004). Sosyal bilgiler öğretiminde işbirlikli öğrenme, öğrenme stilleri, akademik başarı ve cinsiyet ilişkileri. Yayımlanmamış doktora tezi. Dokuz Eylül Üniversitesi Eğitim Bilimleri Enstitüsü, İzmir

Guild, P. B., ve Garger, S. (1998). Marching to different drummers. USA: ASCD, Alexandria.

Gülbahar, Y. (2005). Öğrenme stilleri ve teknoloji. Education and Science, 30(138), 1017.

Güven, M., ve Kürüm, D. (2006). Öğrenme stilleri ve eleştirel düşünme arasındaki ilişkiye ngenel bakış. Sosyal Bilimler Dergisi, 1, 75- 90.

Işıldar, P., Aktaş, E., ve Kurgun, O. A. (2016). Turizm öğrencilerinin vark öğrenme modeline göre öğrenme stillerinin belirlenmesi: lisans ve önlisans karşılaştırması. Dokuz Eylül Üniversitesi Sosyal Bilimler Enstitüsü Dergisi, 18(1), 91-113.

Jahanbakhsh, R. (2012). Learning styles and academic achievement: a case study of Iranian high school girls' students. Social and Behavioral Sciences,51, 10301034.

Kayes, D. C., Kayes, A. ve Kolb, D. A. (2005). Experiantal learning in teams. Simulation and Gaming, 36(3), 330-354.

Karakış, Ö. (2006). Bazı yükseköğrenim kurumlarında farklı öğrenme stillerine sahip olan öğrencilerin genel öğrenme stratejilerini kullanma düzeyleri. Yayımlanmamış Yüksek lisans tezi. Abant İzzet Baysal Üniversitesi, Bolu.

Kaya, A., Bozaslan, H., ve Durdukoca, F.S. (2012). Öğretmen adaylarının öğrenme stilleri ile ders çalışma alışkanlıkları arasındaki ilişkinin. Elektronik Sosyal Bilimler Dergisi, $11 \quad$ (4)1, 983- 1003.

Keefe, J. W. (1979). Learning style: an overview in student learning styles, diagnosing and prescribing program. Reston. VA: National Association of Secondary School Principlas,Connecticut, USA.

Keefe, J. W., ve Ferrell, B.G. (1990). Developing a defensible learning style paradigm. Educational Leadership, 48(1), 57-61.

Kılıç, E. ve Karadeniz, Ş. (2004). Cinsiyet ve Öğrenme Stilinin Gezinme Stratejisi ve Başarıya Etkisi. GÜ, Gazi Eğitim Fakültesi Dergisi, Cilt 24, Sayı 3 (2004) 129146

Klavas, A. (1994). In Greensboro, North Carolina: learning style program boots achievement and test scores. Clearing House, 67(3)149-151.

Lashley, C., ve Barron, A. (2006) The learning style preferences of hospitality and tourism students: Observations from an international and cross-cultural study. Hospitality Managemet, 25, 552- 569.

Lun Su, A. Y. (2012). Learning styles of hospitality students in Taiwan and the United States. $\quad$ The Journal of Human Resource and Adult Learning, 8(2), 10-19. Marriott, P. (2002). A longitudinal study of undergraduate accounting students' learning style preferences at two UK universities. Accounting Education: An International Journal, 11(1), 43-62. 
Molden, D. (2001). NIp business masterclass. Great Britain: Pearson Education Limited

Ormrod, J. E. (2013). Öğrenme psikolojisi. (Mustafa Baloğlu, Çev.). Ankara: Nobel yayıncılık

Park, C.C. (1997b). Learning Style Preferences of Asian Students' in SecondarySchool. Equitiy\&Excellence in Education, 30(2), 68-77.

Picard, C. J. (2000). Activities for the instruction of individual differences amang students, pieces, louisiana teacherAssistance and Assessment Program Louisiana Department of Education, Louisiana.

Reid, J. M. (1987). The learning style preferences of ESL students. Tesol Quarterly, 21(1), 87- 110.

Riding, R. ve Rayner, S. G. (2002): Cognitive Styles and Learning Strategies Understanding Styles Differences in Learning and Behavior, London, David Fulton Publishers..

Seven, M., Bağcivan. G., Kılıç. S., ve Açıkel, C. (2012). Hemşirelik yüksekokulu birinci sınıf Öğrencilerinin öğrenme stillerinin belirlenmesi ve ders başarıları ile ilişkisinin incelenmesi. Gülhane Askeri Tıp Akademisi, 554, 129- 135

Seven, A. M., ve Engin, A.O. (2008). Öğrenmeyi etkileyen faktörler. Atatürk Üniversitesi Sosyal Bilimler Dergisi, 12(2), 189-212.

Siddique, A. Abbas, A., Riaz, F. ve Nazir, R.(2014). An investigation of perceptuallearning style preferences of studentson the basis of gender and academicachievements. Pakistan Journal of Lifeand Social Sciences, 12(1), 26-30.

Stevens, D. P., Kitterlin, M., ve Tanner, J. R. (2012). Assessing the impact of learning styles for hospitality students. Consortium Journal of Hospitality and Tourism, 17, 1-23.

Süral, S. (2008). Sınıf öğretmenliği öğretmen adaylarının öğrenme stilleri ile fen ve teknoloji öğretimi dersindeki akademik başarıları arasındaki ilişki. Yayımlanmamış yüksek lisans tezi, Pamukkale Üniversitesi Sosyal Bilimler Enstitüsü, Denizli

Şeker, M., ve Yılmaz, K. (2011). Sosyal bilgiler öğretiminde öğrenme stillerinin kullanılmasının öğrencilerin öğrenme düzeyleri üzerindeki erkisinin incelenmesi. Kastamonu Eğitim Dergisi, 19(1), 251-266.

Şimşek, N. (2002). BİG 16 öğrenme biçemleri envanteri. Eğitim Bilimleri ve Uygulama, 1, 34- 47.

Terry, W. S. (2007). Öğrenme ve bellek, temel ilkeler, süreçler ve işlemler (B. Cangöz. Çev.). Ankara: Anı Yayıncılık.

Topuz, F. G. ve Karamustafaoğlu, O. (2013). Öğrenme stillerinin çeşitli değişkenler açısından incelenmesi: fen bilgisi öğretmen adayları, DÜ Ziya Gökalp Eğitim Fakültesi Dergisi, (21), 30-46

Tuna, S. (2008). Resim iş öğretmenliğinde öğrencilerin öğrenme stilleri. Elektronik Sosyal Bilimler Dergisi, 7 (25), 252-261.

Tutar, H. (2014). Sosyal piskoloji kavramlar ve kuramlar. Ankara: Seçkin Yayıncılık.

Otrar, M., Gülten, D. Ç., ve Özkan, E. (2012). İlköğretim öğrencilerine yönelik öğrenme stilleri ölçeği geliştirilmesi. Eğitim ve Öğretim Araştırmaları Dergisi, 1 (2), 305318.

Wallace, J. (1995). When teachers' Learning styles differ from those of their students. Journal of Instructional Pscyhology, 22 (1), 99-100.

Washington, N.D., Janosky, E., ve Ann, F. (1990). Learning style preferences and the satisfaciton and performances of student groups. Academic Medicine,65 (14), 716-720.

Watson, S., McGuire, D., ve Barron, P. (2006). A comparative study of Scottish and Australian student preferred learning styles in hospitality and tourism education : 
a progressive perspective. 6th - 9th February 2006. In: 2006 CAUTHE Conference, Melbourne, Australia.

Veznedaroğlu, L. R., ve Özgür, O. A. (2005). Öğrenme stilleri: tanımlar, modeller ve işlevleri. İlkögretim-Online, 4 (2), 1-16.

Yazıcı, H., ve Altun, F. (2013). Üniversite öğrencilerinin içsel ve dışsal motivasyon kaynakları ile akademik başarıları arasındaki ilişki. The Journal of Academic Social Science Studies. 6 (6), 1241-1252.

Yılmaz, G. K., Metin, M., Birişçi, S., ve Coşkun, K. (2010). Öğretmen adayları en iyi nasıl öğrenir? 11-13 November. Internetional Conference on New Trends in education and Their Implications, Antalya- Turkey. 239- 244.

Yurtseven, R. (2010). Illköğretim beşinci sınıf öğrencilerinin sosyal bilgiler dersindeki akademik başarıları ile öğrenme stilleri arasındaki ilişkisi. Yayımlanmamış yüksek lisans tezi Afyon Kocatepe Üniversitesi Sosyal Bilimler Enstitüsü, Afyon. 